\title{
Trends in Area, Production, Yield and Export-Import of Cashew in India- An Economic Analysis
}

\author{
Mahantesh Nayak ${ }^{1 *}$ and Manjunatha Paled ${ }^{2}$ \\ Department of Agricultural Economics, College of Agriculture, Dharwad, UAS Dharwad - \\ 580 005, Karnataka, India \\ *Corresponding author
}

\begin{tabular}{|l|}
\hline Ke y w or d s \\
Cashew, CAGR, \\
Productivity, Export \\
and Import
\end{tabular}

\section{Introduction}

The cashew tree (Anacardium occidentale L.), native of Brazil, was introduced to Mozambique and then to India in the sixteenth century by the Portuguese as a means of controlling coastal erosion. It was spread within these countries with the aid of elephants that ate the bright cashew fruit along with the attached nut. The nut was too hard to digest and was later expelled with the droppings. It was not until the nineteenth century that plantations were developed and the tree then spread to a number of other countries in Africa, Asia and Latin America (Hareesh, 2009). The Portuguese traders thus introduced the cashew tree into India and Africa to prevent soil erosion. Cashew is now widely cultivated for its kernel, fruit, cashew nut shell liquid and other products. However, it is mostly found in the coastal regions of South Africa, Madagascar, Tanzania, and South Asia, from Sri Lanka to the Philippines. 
India is the largest producer, processer, consumer and exporter of cashew in the world (Elakkiya et al., 2017). The current Cashewnut production in India accounts for 45 per cent of the global production. India being the leader in the world in raw Cashew nut production and is also the largest supplier of cashew kernels to the major world markets. It is grown in Kerala, Karnataka, Goa, and Maharashtra along the West coast and Tamil $\mathrm{Nadu}$, Andhra Pradesh, Odissa and West Bengal along the East-coast, occupies an area of 10.30 lakh hectares in the country with a production of 9.98 lakh metric tonnes. Even though strong competition from other countries has reduced India's share in the global cashew exports, India's advantage in terms of less percentage of broken kernels has brought European and US buyers to its proximity. To strengthen cashew exports, there is scope for increasing production by developing cashew as plantation crop on commercial basis, exploring new markets and strengthening non-traditional markets, adding value to the product by introducing innovations in processing and branding them. Among the major states in the country, Maharashtra tops with respect to area, production and productivity of cashew nut.

Keeping in view the importance of cashew in the Indian economy in general and its major growing states in particular, the present study made an attempt to analyze the trends in area, production, yield and export and import of cashew in India.

\section{Materials and Methods}

\section{Nature and sources of data}

The study is based on secondary data collected from different sources for achieving the objectives of the study. Secondary data was collected from various sources like websites, Directorate of Cashewnut and Cocoa
Development, Cochin, www.indiastat.cometc.

\section{Analytical tools}

For the purpose of evaluating the objectives of the study, based on the nature and extent of data availability, the following analytical tools will be used for analyzing the data to draw meaningful results and conclusions. State-wise area, production, yield prices and exportimport of Cashewnut in India has been collected and analyzed by using standard statistical tools like arithmetic mean and coefficient of variation, compound growth rates and graphical representations to know the trends in area, production and productivity of cashew in India.

\section{Compound annual growth rate analysis}

To study the annual growth rate in quantity and value of export of coir products, the compound growth rate was computed using semi-log or exponential model (Kulkarni et. al. 2012).

\section{$\ln Y_{t}={ }^{\alpha}{ }_{+}^{\beta}{ }_{t}+u_{t}$}

Where,

$Y_{t}=$ Quantity (tonnes) of coir products exported in year $t$.

$\mathrm{t}=$ Time element which takes the value 1,2 $n$ for various years.

$$
\begin{aligned}
& \alpha=\text { Intercept } \\
& \beta_{t}=\text { Regression co-efficient }
\end{aligned}
$$

Compound Annual Growth Rate (CAGR) $=$ [(Antilog $\left.\left.\left.\beta_{\mathrm{t}}\right)-1\right) \times 100\right]$

\section{Co-efficient of variation (CV)}

It explains the fluctuations over the period as follows: 
$C V=\frac{\sigma}{\bar{X}} * 100$

$\mathbf{C V}=$ Co-efficient of variation

$\sigma=$ Standard deviation

$\overline{\boldsymbol{X}}=$ Mean

\section{Results and Discussion}

The findings of the present study as well as appropriate discussion have been summarized under following heads:

\section{Trends in area, production and yield of raw Cashewnut in India (1980-81 to 2017-18)}

In India, cashew cultivation is largely found in Kerala, Karnataka, Goa and Maharashtra along the west coast and Tamil Nadu, Andhra Pradesh, Orissa and West Bengal along the east coast. Area under cashew nuts in India has increased by more than two folds gradually from 464 thousand hectares in198081 to 1062 thousand hectares during 2017-18 (Table 1). Total cashew production has increased by more than four folds from 185 thousand metric tonnes in $1980-81$ to 817 thousand tonnes in 2017-18. With respect to productivity, during 1980-81 it was very low at $399 \mathrm{~kg}$ per hectare and shown an upward trend i.e., yield increased to $769 \mathrm{~kg}$ per hectare which is less than two folds. We can see a gradual increase in area under cashew with less fluctuation but trends in production and yield are more fluctuating over the years. More sharp fluctuation is observed in the period between from 1987-88 to 1992-93. Pattern of yield follows the pattern of production in most of the years (Fig. 1).

The compound annual growth rate (CAGR)for area under Cashewnut (Table 1) has found to be 2.33 per cent per year which is significant at one per cent probability level. The growth in production was found to be 3.97 per cent per year (significant at one per cent) which is more than the growth in area under cashew. While the growth in yield of cashew was found to be 1.60 per cent per year which is lower than growth in both area and production. Major reasons attributing to low productivity in the country are:

- Use of low yielding local varieties

- Planting of cashew in marginal and poor fertile land

- Non-adoption of recommended package of practices

- Pest infestation (tea mosquito bug and cashew stemand root borer) leading to yield reduction up to 30 to 40 percent (Kulkarni et al., 2012).

With respect to fluctuations in area under cashew measured in terms of co-efficient of variation $(\mathrm{CV})$ is found to be 26.27 per cent per year. These variations in area under cashew might be due to endemic disease and pest outbreak and also price level. While variations in production was found to be 40.64 per cent per year and that of for yield was 24 per cent per year. Fluctuations are more in production might be due to pest and disease outbreak, floods, landslides and also fluctuations in price level of cashew.

\section{State-wise area, production and yield of cashew during 2016-17}

State-wise share in area, production and yield of cashew during 2016-17 are presented in Table 2. It is observed that in India cashew plantation area was 1040.89 thousand hectares of which Maharashtra had more area with 186.20 thousand hectares $(17.89 \%$ of the total area) followed by Andhra Pradesh with 185.57 thousand hectares (17.83\% of the total area), Odisha with 183.32 thousand hectares $(17.61$ $\%$ of the total area), Tamil Nadu (13.60\% of the total area), Karnataka (12.28\% of the total 
area) and so on. With respect to production, in India total production was found to be 779.34 thousand metric tonnes of Maharashtra alone produced 256.61 thousand metric tonnes ( $32.93 \%$ of the total production) followed by Andhra Pradesh with 111.39 thousand metric tonnes (14.29\% of the total production) and Odisha with 93.9 thousand metric tonnes (12.05\% of the total production) and so on. With respect to productivity, average yield of cashew in India was found to be $762 \mathrm{~kg}$ per hectare. Maharashtra stands in first position with productivity of $1378 \mathrm{~kg}$ per hectare which is almost double the national average yield. This might be due to availability suitable climatic conditions, soil type, land topography and adoption of improved cultivation practices.

\section{State-wise price trends of raw cashew (1990-91 to 2017-18)}

State-wise price trends of raw cashew from 1990-91 to 2017-18 are presented in Table 3. It is observed from table that during 1990-91 average price of raw cashew was found to be highest in Goa state (Rs. 17/kg.) followed by Karnataka (Rs. 15/kg.), average of prices in all the states was found to be Rs. $14 / \mathrm{kg}$. We can see an increasing trend in prices over the years in all the states. Growth in prices was found to be highest in Karnataka state $(6.61 \%$ per year) followed by Kerala (6.22\% per year) while growth at average prices in all these states was 6.16 per cent per annum. Growth rates in all the states are significant at one per cent. Fluctuations in price in terms of co-efficient of variation $(\mathrm{CV})$ is found to be highest in Karnataka state $(72.31 \%)$ followed by Kerala (65.60\%) while $\mathrm{CV}$ in average price is 62.13 per cent (Fig. 2).

We can observe from the figure 3 that increase in prices in all states was almost gradual up to 2010-11 thereafter; there is a sharp increase in prices in all the states. This might be due to sudden increase in demand for cashew nuts on account of nutritional consciousness of the consumers.

\section{Export and import performance of cashew}

India has been exporting cashew kernel from long back to various countries like US, UAE, Netherlands, Japan, etc. and importing raw cashew nuts for processing from abroad. Cashew nut shell liquid (CNSL) is a byproduct which is obtained in processing of raw cashew and India is exporting this also.

During 2006-07 India has exported 1,18,540 metric tonnes of cashew kernels with a value of Rs. 2,455.15 crore (Table 4). There is a decreasing trend in quantity of cashew kernel exported and has come down to 82,302 metric tonnes with a value of Rs. 5,168.78 crore during 2016-17 even though there is an increasing production over the years. It might be due to the reason that now a day health consciousness of the people has been improving on account of this there might be increase in demand for cashew kernel in domestic markets. The rate of decline in export is found to be 2.13 per cent $(-2.13 \%)$ per annum which is significant at five per cent and co-efficient of variation was found to be 12.20 per cent.

With respect to import of raw cashew, during 2006-07 India has imported 5,92,604 metric tonnes with a value of Rs. 1811.62 crore (Table 4). In contrast to export there is an increasing trend in quantity imported over the years. During 2016-17 quantity of raw cashew imported has rose to 7,70,446 metric tonnes with a value of Rs. 8,839.42 crore. The reason for this might be due to increasing processing capacity in India on account of increase in number of processing units. The rate of increase in import was found to 4.67 per cent per annum. Per annum variation in quantity imported was 19.78 per cent. 
During 2006-07, India has exported 6139 metric tonnes of cashew nut shell liquid (CNSL) with a value of Rs. 10.29 crores (Table 4). Over the years, quantity of export of CNSL has increased up to 2011-12 and decreased during 2012-13 and 2013-14 and again increased thereafter and during 2016-17 quantity of CNSL exported was 11,422 metric tonne worth Rs. 44 crores.

Trends in state-wise area under raw Cashewnut from 1993-94 to 2016-17

It is seen from the Figure 4 that Kerala had more area under cashew during 1993-94 compared to other states. All states showed a positive growth in area over the years except
Kerala where a negative growth is seen up to 2007-08 thereafter a slight positive trend has seen. The reason for this are felling of cashew trees, conversion of cashew area into rubber plantations, rising in prices and conversion cashew into turmeric in small patches (Senthil and Mahesh, 2013). In Goa and West Bengal only a slight increase in area (more or less same area) over the years is seen. In Karnataka and Tamil Nadu gradual increase has seen over the years. In Andhra Pradesh, Maharashtra and Orissa there seen a more rapid increase in area compared to other states. During 2016-17 area under cashew in Andhra Pradesh, Maharashtra and Orissa almost become same.

Table.1 Trends in area, production and yield of cashew in India (1980-81 to 2017-18)

\begin{tabular}{|c|c|c|c|c|c|c|c|}
\hline Year & $\begin{array}{c}\text { Area } \\
\text { (‘000’ ha) }\end{array}$ & $\begin{array}{l}\text { Production } \\
\text { ('000’ MT) }\end{array}$ & $\begin{array}{l}\text { Yield } \\
\text { (kg/ha) }\end{array}$ & Year & $\begin{array}{c}\text { Area } \\
\text { ('000’ ha) }\end{array}$ & $\begin{array}{l}\text { Production } \\
\text { ('000’ MT) }\end{array}$ & $\begin{array}{c}\text { Yield } \\
\text { (kg/ha) }\end{array}$ \\
\hline 1980-81 & 464 & 185 & 399 & $2000-01$ & 720 & 450 & 625 \\
\hline 1981-82 & 481 & 196 & 407 & 2001-02 & 770 & 472 & 613 \\
\hline 1982-83 & 492 & 201 & 409 & 2002-03 & 770 & 506 & 657 \\
\hline $1983-84$ & 504 & 191 & 379 & 2003-04 & 780 & 535 & 686 \\
\hline 1984-85 & 510 & 221 & 433 & 2004-05 & 820 & 544 & 663 \\
\hline 1985-86 & 722 & 234 & 324 & 2005-06 & 837 & 573 & 685 \\
\hline 1986-87 & 523 & 246 & 470 & 2006-07 & 854 & 620 & 726 \\
\hline 1987-88 & 527 & 260 & 493 & $2007-08$ & 868 & 665 & 766 \\
\hline 1988-89 & 529 & 274 & 518 & 2008-09 & 893 & 695 & 778 \\
\hline 1989-90 & 541 & 530 & 980 & 2009-10 & 923 & 613 & 664 \\
\hline 1990-91 & 532 & 295 & 555 & $2010-11$ & 945 & 653 & 691 \\
\hline $1991-92$ & 534 & 534 & 1000 & 2011-12 & 979 & 725 & 741 \\
\hline 1992-93 & 560 & 349 & 623 & 2012-13 & 991 & 752 & 759 \\
\hline 1993-94 & 565 & 348 & 616 & 2013-14 & 1011 & 753 & 745 \\
\hline 1994-95 & 577 & 322 & 558 & 2014-15 & 1030 & 745 & 723 \\
\hline 1995-96 & 635 & 418 & 658 & 2015-16 & 1037 & 671 & 647 \\
\hline 1996-97 & 659 & 430 & 653 & 2016-17 & 1041 & 779 & 762 \\
\hline 1997-98 & 701 & 360 & 514 & $2017-18$ & 1062 & 817 & 769 \\
\hline 1998-99 & 706 & 460 & 652 & CAGR $(\%)$ & $2.33 * *$ & $3.97 * *$ & $1.60 * *$ \\
\hline 1999-00 & 686 & 520 & 758 & CV (\%) & 26.27 & 40.64 & 23.99 \\
\hline
\end{tabular}


Table.2 State-wise area, production and yield of cashew in India (2016-17)

\begin{tabular}{|l|c|c|c|c|c|}
\hline \multicolumn{1}{|c|}{ State } & $\begin{array}{c}\text { Area } \\
(000 \mathrm{ha})\end{array}$ & \% Share & $\begin{array}{c}\text { Production } \\
(000 \mathrm{MT})\end{array}$ & $\%$ Share & Yield (kg/ha) \\
\hline Kerala & 90.87 & 8.73 & 83.98 & 10.78 & 962 \\
\hline Karnataka & 127.86 & 12.28 & 85.15 & 10.93 & 672 \\
\hline Goa & 58.18 & 5.59 & 32.66 & 4.19 & 561 \\
\hline Maharashtra & 186.20 & 17.89 & 256.61 & 32.93 & 1378 \\
\hline Tamil Nadu & 141.58 & 13.60 & 67.65 & 8.68 & 478 \\
\hline Andhra Pradesh & 185.57 & 17.83 & 111.39 & 14.29 & 600 \\
\hline Odisha & 183.32 & 17.61 & 93.9 & 12.05 & 513 \\
\hline West Bengal & 11.36 & 1.09 & 12.96 & 1.66 & 1140 \\
\hline Jharkhand & 14.83 & 1.42 & 5.83 & 0.75 & 393 \\
\hline Chhattisgarh & 13.70 & 1.32 & 9.33 & 1.20 & 681 \\
\hline Gujarat & 7.22 & 0.69 & 6.5 & 0.83 & 900 \\
\hline Pondichery & 5 & 0.48 & 2.16 & 0.28 & 432 \\
\hline Tripura & 4.25 & 0.41 & 3.45 & 0.44 & 812 \\
\hline Others & 10.95 & 1.05 & 7.77 & 1.00 & 710 \\
\hline Total (India) & $\mathbf{1 0 4 0 . 8 9}$ & $\mathbf{1 0 0}$ & $\mathbf{7 7 9 . 3 4}$ & $\mathbf{1 0 0}$ & $\mathbf{7 6 2}$ \\
\hline
\end{tabular}

Table.4 Export and import of Cashew (2006-07 to 2016-17)

\begin{tabular}{|c|c|c|c|c|c|c|}
\hline \multirow{2}{*}{ Year } & \multicolumn{2}{|c|}{ Cashew Kernel Export } & \multicolumn{2}{c|}{$\begin{array}{c}\text { Cashew Nut Shell } \\
\text { Liquid Export }\end{array}$} & \multicolumn{2}{c|}{ Rawnut Import } \\
\cline { 2 - 7 } & Quantity & Value & Quantity & Value & Quantity & Value \\
\hline $\mathbf{2 0 0 6 - 0 7}$ & $1,18,540$ & 2455.15 & 6,139 & 10.29 & $5,92,604$ & 1811.62 \\
\hline $\mathbf{2 0 0 7 - 0 8}$ & $1,14,340$ & 2289.02 & 7,813 & 11.98 & $6,05,970$ & 1746.80 \\
\hline $\mathbf{2 0 0 8 - 0 9}$ & $1,09,522$ & 2988.40 & 9,099 & 26.06 & $6,05,850$ & 2632.41 \\
\hline $\mathbf{2 0 0 9 - 1 0}$ & $1,17,991$ & 2801.60 & 11,227 & 27.62 & $7,55,959$ & 3047.50 \\
\hline $\mathbf{2 0 1 0 - 1 1}$ & $1,05,755$ & 2819.39 & 12,051 & 33.77 & $5,29,370$ & 2649.56 \\
\hline $\mathbf{2 0 1 1 - 1 2}$ & $1,31,760$ & 4390.68 & 13,575 & 59.46 & $8,09,371$ & 5337.76 \\
\hline $\mathbf{2 0 1 2}-13$ & $1,00,105$ & 4067.21 & 9,192 & 29.84 & $8,92,160$ & 5331.12 \\
\hline $\mathbf{2 0 1 3 - 1 4}$ & $1,14,791$ & 5058.73 & 9,480 & 30.61 & $7,71,356$ & 4563.99 \\
\hline $\mathbf{2 0 1 4 - 1 5}$ & $1,18,952$ & 5432.85 & 10,938 & 55.81 & $9,39,912$ & 6570.93 \\
\hline $\mathbf{2 0 1 5 - 1 6}$ & 96,346 & 4952.12 & 11,677 & 57.59 & $9,58,339$ & 8561.01 \\
\hline $\mathbf{2 0 1 6 - 1 7}$ & 82,302 & 5168.78 & 11,422 & 44.00 & $7,70,446$ & 8839.42 \\
\hline CAGR & $\mathbf{- 2 . 1 3 2 7} *$ & & $\mathbf{4 . 3 2} *$ & & $\mathbf{4 . 6 7} * *$ & \\
\hline (\%) & & & & & & \\
\hline CV $(\%)$ & $\mathbf{1 2 . 2 0}$ & & $\mathbf{2 0 . 7 2}$ & & $\mathbf{1 9 . 7 8}$ & \\
\hline
\end{tabular}


Table.3 State-wise price trends of raw cashew (1990-91 to 2017-18)

\begin{tabular}{|c|c|c|c|c|c|c|}
\hline Year & Kerala & Karnataka & $\begin{array}{l}\text { Andhra } \\
\text { Pradesh }\end{array}$ & Tamil Nadu & Goa & Average price \\
\hline 1990-91 & 12 & 15 & 13 & 13 & 17 & 14 \\
\hline 1991-92 & 15 & 20 & 18 & 21 & 23 & 19 \\
\hline $1992-93$ & 22 & 26 & 21 & 24 & 29 & 24 \\
\hline 1993-94 & 21 & 20 & 20 & 20 & 24 & 21 \\
\hline 1994-95 & 21 & 22 & 23 & 23 & 30 & 24 \\
\hline 1995-96 & 25 & 26 & 26 & 28 & 32 & 27 \\
\hline 1996-97 & 29 & 29 & 29 & 29 & 30 & 29 \\
\hline 1997-98 & 26 & 22 & 30 & 24 & 33 & 27 \\
\hline 1998-99 & 31 & 25 & 30 & 24 & 33 & 29 \\
\hline 1999-00 & 42 & 28 & 34 & 25 & 47 & 35 \\
\hline 2000-01 & 42 & 27 & 35 & 35 & 36 & 35 \\
\hline 2001-02 & 27 & 28 & 28 & 29 & 34 & 29 \\
\hline 2002-03 & 25 & 28 & 35 & 35 & 34 & 31 \\
\hline 2003-04 & 30 & 32 & 28 & 35 & 36 & 32 \\
\hline 2004-05 & 29 & 30 & 29 & 36 & 35 & 32 \\
\hline 2005-06 & 38 & 35 & 38 & 48 & 45 & 41 \\
\hline 2006-07 & 31 & 31 & 29 & 37 & 38 & 33 \\
\hline 2007-08 & 30 & 31 & 29 & 36 & 38 & 33 \\
\hline 2008-09 & 34 & 34 & 30 & 37 & 47 & 36 \\
\hline 2009-10 & 42 & 42 & 41 & 43 & 47 & 43 \\
\hline 2010-11 & 40 & 52 & 52 & 53 & 55 & 50 \\
\hline 2011-12 & 71 & 71 & 70 & 71 & 83 & 73 \\
\hline 2012-13 & 60 & 61 & 59 & 61 & 77 & 63 \\
\hline 2013-14 & 52 & 53 & 53 & 56 & 73 & 57 \\
\hline 2014-15 & 61 & 78 & 74 & 64 & 87 & 73 \\
\hline 2015-16 & 90 & 115 & 75 & 72 & 122 & 95 \\
\hline 2016-17 & 100 & 113 & 100 & 81 & 130 & 105 \\
\hline 2017-18 & 133 & 137 & 114 & 102 & 142 & 126 \\
\hline $\begin{array}{c}\text { CAGR } \\
(\%)\end{array}$ & $6.22 * *$ & $6.61 * *$ & $5.95 * *$ & $5.78 * *$ & $5.78 * *$ & $6.16 * *$ \\
\hline $\begin{array}{l}\text { CV } \\
(\%)\end{array}$ & 65.60 & 72.31 & 60.07 & 51.51 & 63.92 & 62.13 \\
\hline
\end{tabular}


Figure.1 Trends in area, production and yield of cashew (1980-81 to 2017-18)

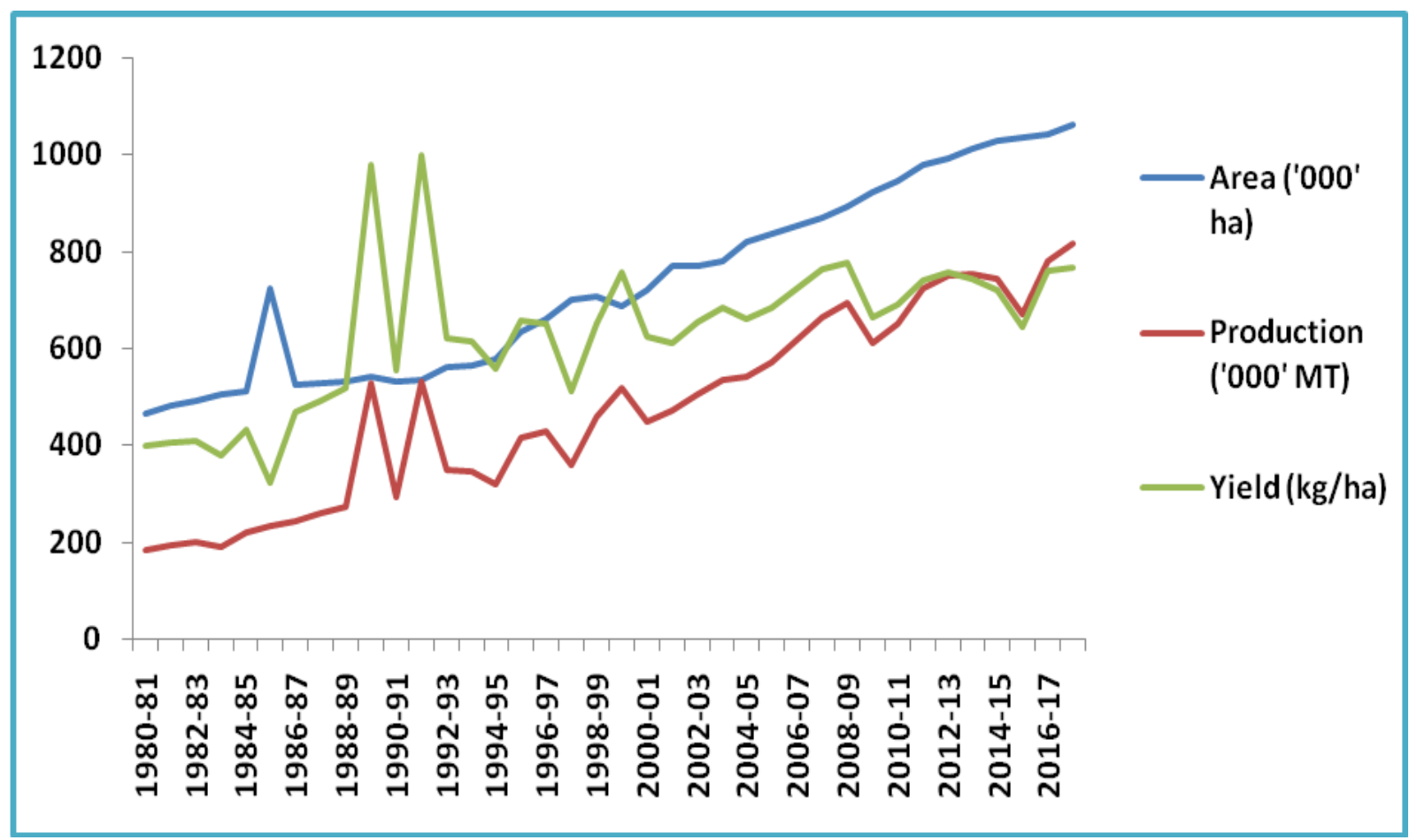

Figure.2 Comparison of cashew yield levels in different states

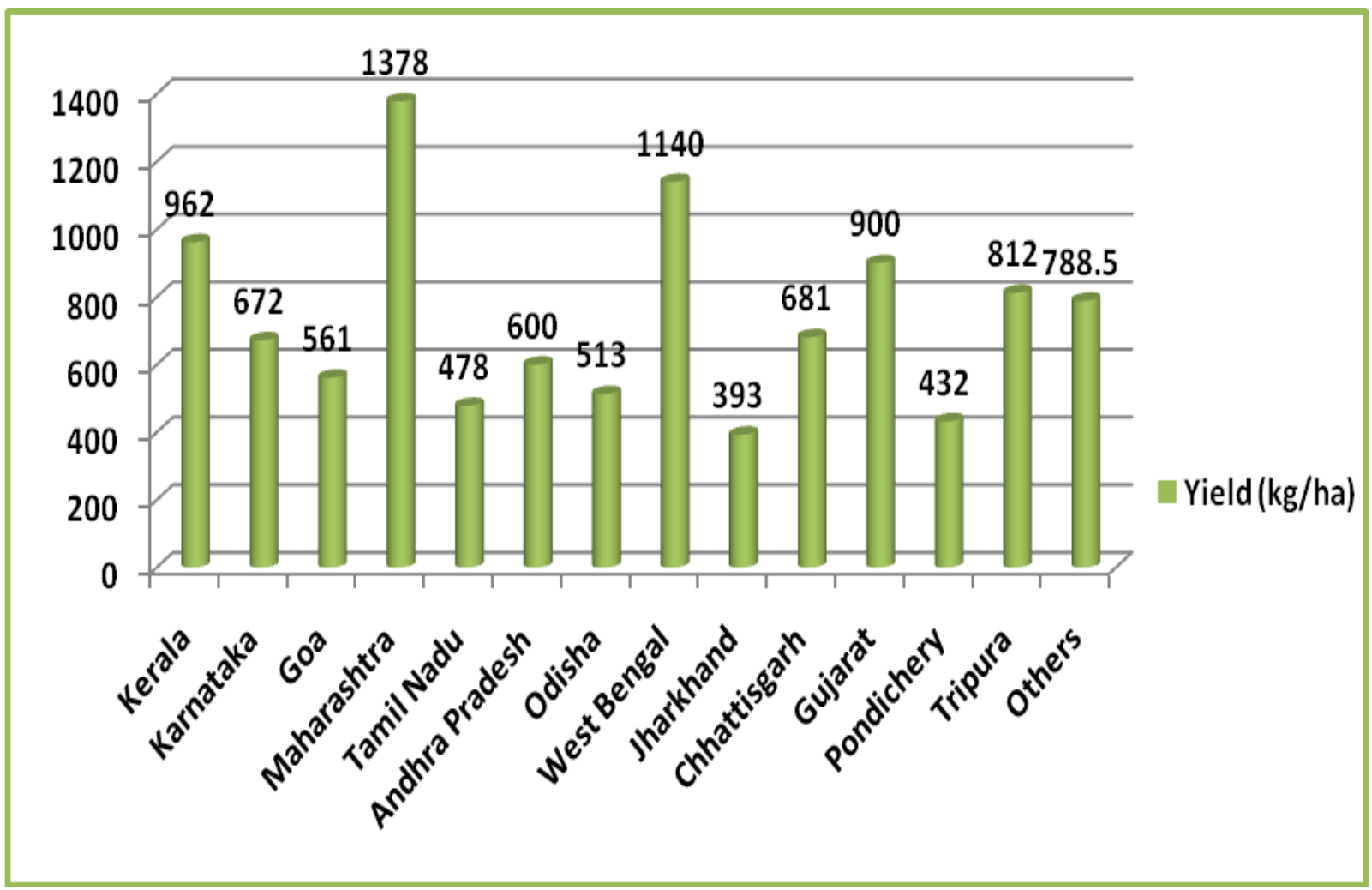


Figure.3 Trends in prices of raw cashew from 1990-91 to 2017-18

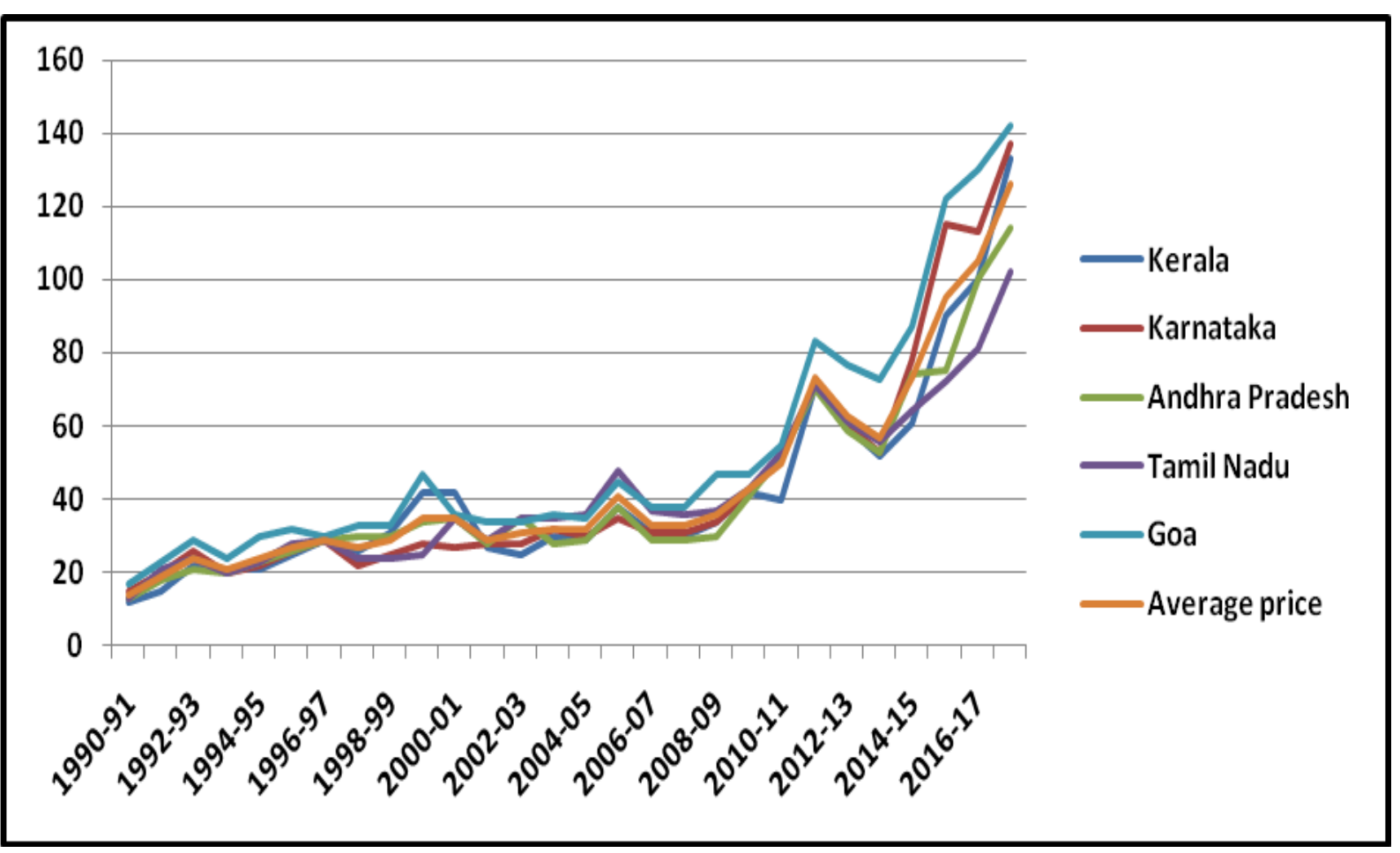

Figure.4 Trends in state-wise area under raw Cashewnut from 1993-94 to 2016-17

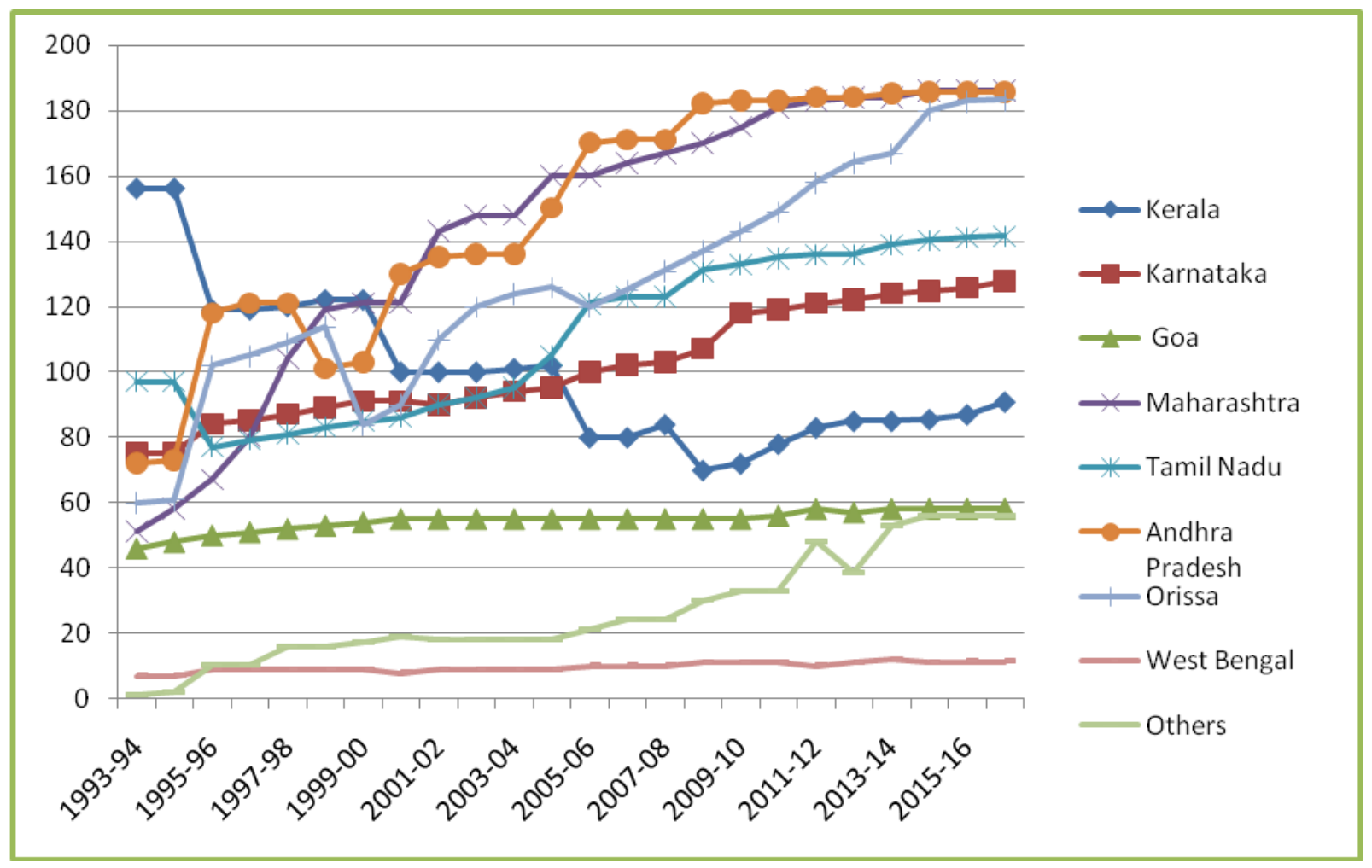


Figure.5 Trends in state-wise production of raw Cashewnut from 1993-94 to 2016-17

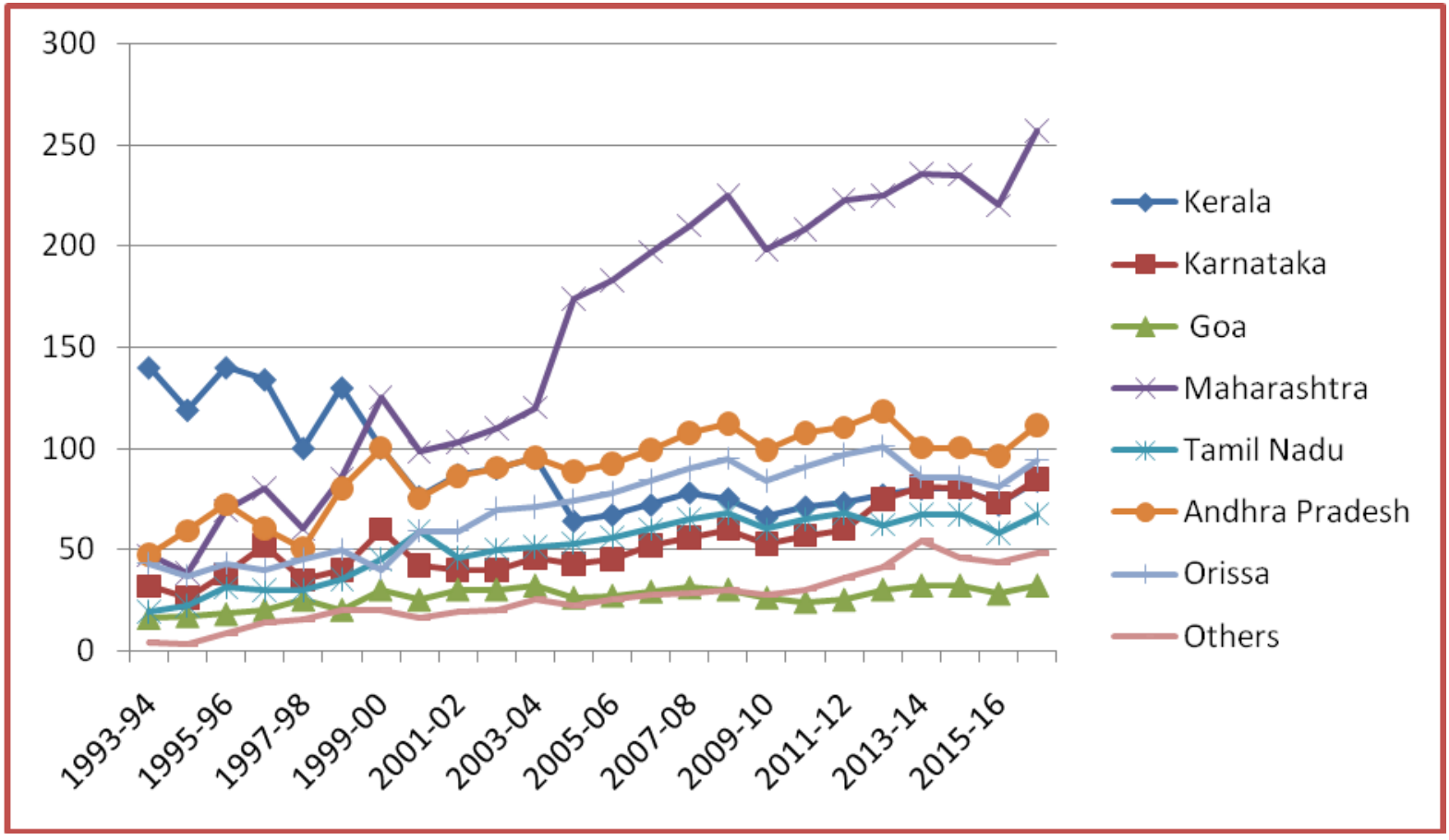

Figure.6 Trends in state-wise yield of raw Cashewnut from 1993-94 to 2016-17

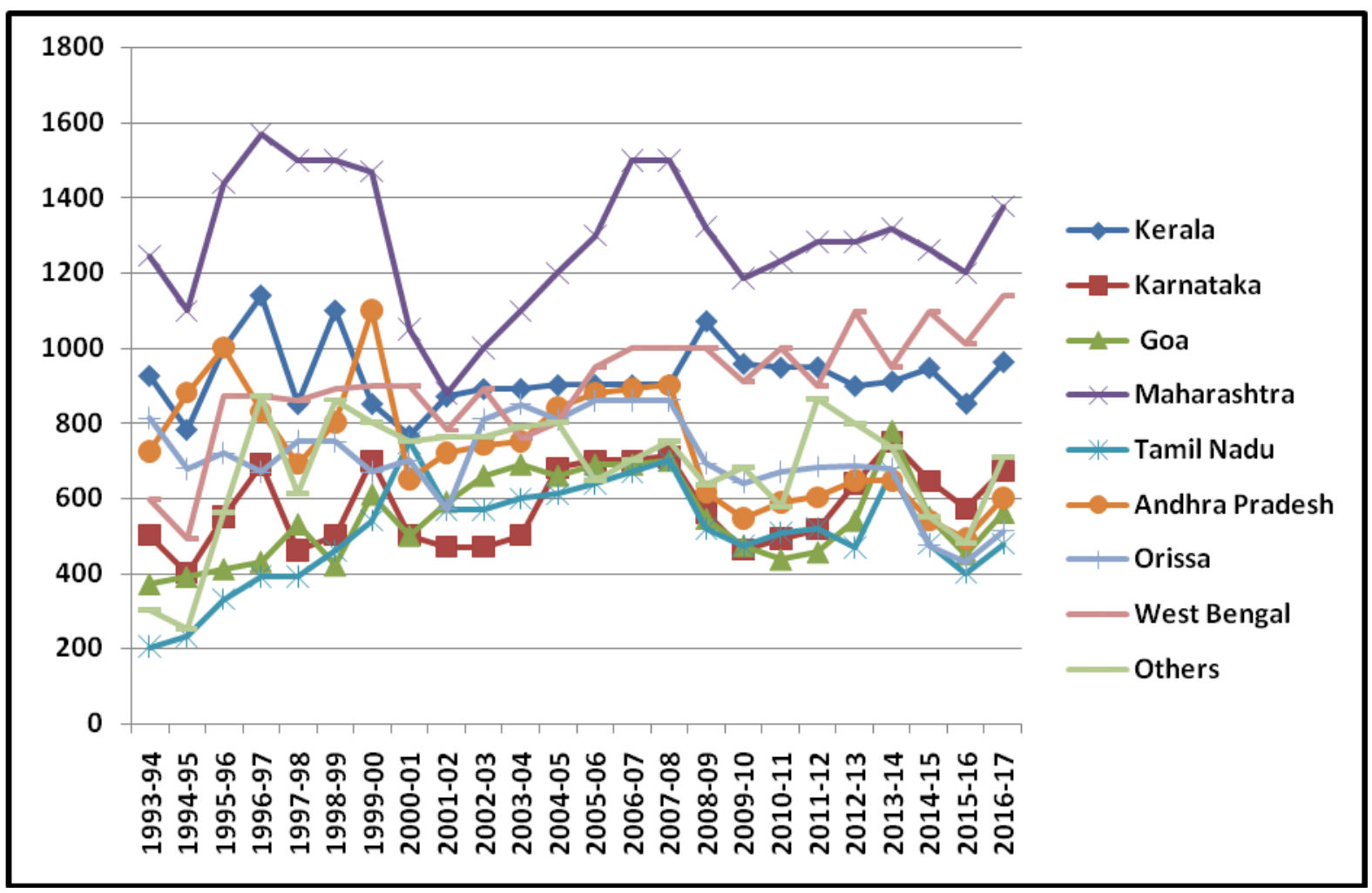


Trends in state-wise production of raw Cashewnut from 1993-94 to 2016-17

It is seen from Figure 5 that during 1993-94 like area under cashew, production was also highest in Kerala and shown a decreasing trend up to 2004-05, thereafter become positive. In all states production showed a gradual positive trend over the years but in Maharashtra production has hiked more rapidly compared to other states.

Trends in state-wise yield of raw Cashewnut from 1993-94 to 2016-17

It is evident from the Figure 6 that productivity remained higher in Maharashtra throughout the study period (1993-94 to 2016-17) with fluctuations. But productivities in remaining states are par below compared to productivity in Maharashtra. This might be due availability of most suitable climatic and soil conditions, land topography and agronomic practices of the farmers, etc. All states shown huge fluctuations in yield over the years, this again might be due to climatic variability. Hence there is more scope to increase and maintain stability in productivity.

In conclusion, lLarge area under cashew is grown with poor quality seedlings. Compared to other plantation crops, cashew is mostly restricted to marginal and poor fertile lands and is considered as a wasteland crop. Moreover, cashew has been considered as 'maintenance free' crop and the recommended package of practices are not followed. All these factors lead to low yield. Growth in both area and production is highest in Maharashtra state indicating immense scope to increase area and production in the state. Nearly one third of the total national cashew production is from
Maharashtra only (32.93\%) and productivity is also highest in Maharashtra state $(1378 \mathrm{~kg} / \mathrm{ha})$. There is also more scope to boost the area and production of cashew that ultimately leads to productivity in other states by the usage of improved cultivars and adopting scientific cultivation practices. Since demand for cashew kernel is increasing demand for raw cashew is also increasing. To meet this domestic demand quantity imported is increasing and export of cashew kernels is decreasing over the years.

\section{References}

Elakkiya, E., Sivaraj, P. and Vijayaprabhakar, A. 2017. Growth and Performance of Cashew Nut Production in India- An Analysis. International Journal of Current Microbiology and Applied Sciences. 6(6):1817-1823.

Harish Kumar, K. 2009. An Economic Analysis of Processing and Export Trade of Cashew. M. Sc. Thesis. University of Agricultural Sciences, GKVK, Bengaluru -560065 .

Kulkarni, B. S., Ramachandra, V. A. and Patil, S. M. 2012. Trends in area, production and productivity of cashew in India- An economic analysis. International Journal of Commerce and Business Management. 5(2):128-133.

Senthil, A. and Mahesh, M. P. 2013. Analysis of Cashew Nut Production in India. Asia Pacific Journal of Marketing \& Management Review. 2 (3):106-110.

Cashew Export Promotion Cell of India and Directorate General of Commercial Intelligence and Statistics, Kolkatta

Directorate of Cashewnut \& Cocoa Development, Cochin, GoI

www.indiastat.com

\section{How to cite this article:}

Mahantesh Nayak1 and Manjunatha Paled. 2018. Trends in Area, Production, Yield and ExportImport of Cashew in India-An Economic Analysis. Int.J.Curr.Microbiol.App.Sci. 7(12): 1088-1098. doi: https://doi.org/10.20546/ijcmas.2018.712.135 